\title{
Postnatal Developmental Anatomy of Testes and Epididymis of Gaddi Goats
}

\author{
Desarrollo Anatómico Postnatal de los Testículos y Epidídimo de Cabras Gaddi.
}

\author{
Archana Pathak*; R. S. Katiyar*; D. N. Sharma* \& M. M. Farooqui*
}

\begin{abstract}
PATHAK, A.; KATIYAR, R. S.; SHARMA, D. N. \& FAROOQUI, M. M. Postnatal developmental anatomy of testes and epididymis of gaddi goats. Int. J. Morphol., 32(4):1391-1398, 2014.

SUMMARY: The study revealed that the testes of one-day-old Gaddi goats have descended in the scrotum along with adnexa. They were elongated compressed latero-medially and became ovoid during their postnatal growth and morphogenesis. The two testes were not different significantly in their weight and measurement. The average weight which was about $2.9 \mathrm{gm}$ at birth grew to $107 \mathrm{gm}(40 \mathrm{X})$ in pubertal animals and nearly maintained it during the post-puberty $(113 \mathrm{~g})$. The mean length $(1.46 \mathrm{~cm})$, width $(0.85 \mathrm{~cm})$ and thickness $(0.62 \mathrm{~cm})$ also grew by 47,60 , and 83 times, respectively. In post-pubertal animals it measured $7.06 \times 5.20 \times 5.10 \mathrm{~cm}$. The study indicated a very fast growth of the testes from birth to puberty, which did not alter significantly after that. A relatively much faster growth in thickness and width over the length was the reason behind the change of the morphology from more elongated shape at birth to ovoid shape on maturity. The mediastinum testis was grossly discernible in the testis even at birth. Epididymis was identifiable into caput, corpus and cauda. The gross linear mensuration of these components did not differ in the caput and cauda regions on either side, whereas the length of corpus was more on the left side in all age group of animals. The growth curve revealed a continuous growth of all segments, but the fastest growth occurred in the early postnatal life (at 12-18 month age).
\end{abstract}

KEY WORDS: Postnatal developmental; Anatomy; Testes; Epididymis; Gaddi goats.

\section{INTRODUCTION}

The testis is the seat of production of male germ cells while the epididymis serves as its chief duct system, besides providing the nutrition and ambient for their growth and maturation. Fragmentary anatomical reports on the anatomy of testis of Malabari goats (Harshan et al., 1978), Assam goats (Baishya et al., 1985, 1986), Maradi (Red Sokoto) goats (Ogwuegbu et al., 1985; Nwoha, 1995), Beetal goats (Gupta, 1989), German Brown, Anglo Nubian goats and Caninde goats (Barnabe et al., 1992), Cashmere goats (Walkden-Brown et al., 1994) and Japanese Tokara goats (Nishimura et al., 2000) are available. The Gaddi goats which are the inhabitants of North Western Himalayas of India and lend a vital support to the livelihood of the local tribes have not been utilized for such study so far (Pathak et al., 2012). The present paper reports the basic anatomical data on the testes and epididymis of Gaddi goats at different ages and state of reproduction.

\section{MATERIAL AND METHOD}

Studies were conducted on the male genital organs obtained from 30 apparently healthy goats of pure Gaddi breed with no previous history of genital disorders brought to the abattoir or the local Veterinary Hospital. The samples $(n=30)$ were classified into 3 age groups 1 . Prepubertal (birth to $<18$ months age), 2. Pubertal (>18 months to $<5$ years age) and 3 . Postpubertal ( $>5$ year age) with 10 animals in each. Age (estimated by tooth eruption) and medical history was also confirmed by the owner during the antemortem examination. Immediately after sacrifice, the detailed dissection of male genital organs was done to record the gross morphology (in situ) and topography of each organ separately in each animal. The organs were then isolated from the cadaver and the following morphometrical mensurations were recorded on each organ bilaterally in each animal. Linear measurements were recorded by using a Vernier's caliper and the organ weight were recorded on a Salter monopan digital balance. Following, measurements were recorded on the testes and adnexa together and the epididymis.

Weight of testes: The weight of the testis along with the adnexa was taken on a Salter mono pan digital weighing machine.

Length of testes: Distance between the caputal and caudal extremities of the testis excluding epididymis. 
Width of testes: The distance between the lateral and medial surfaces of the testes was recorded at three points- i) at the point of expanse of caput epididymis over the caputal extremity of the testes, ii) in the mid length of testes, iii) at the broadest point of the attachment of cauda epididymis along the caudal extremity of testis.

Thickness: The distance between the free border and attached borders of the testes was recorded at the same three points as stated above for width measurement.

Diameter: The diameter of the testis was calculated (Width+Thickness/2) at the same three points as stated for the measurements of width and thickness.

Length of caput epididymis: It was recorded by running the non stretchable thread all along the " $\mathrm{S}$ " shaped curvature of the head and then measuring it on the Vernier scale.

Width of caput epididymis: It was recorded at the widest segment of the caput.

Thickness of caput epididymis: It was recorded as the maximum height of the expanded portion of the caput.

Length of corpus epididymis: It was recorded as the length of epididymis along the attached border of testes between the caput and cauda.

Width of corpus epididymis: It was recorded as the distance between the lateral and medial walls of corpus epididymis in the middle of its length.

Thickness of corpus epididymis: It was measured as the distance between the anterior and posterior walls of the epididymis in the middle of the corpus.

Length of cauda epididymis: It was measured from its point of attachment with the caudal extremity of the testes to its ventral most level.

Width of cauda epididymis: It was recorded as the distance between the lateral and medial surfaces of cauda.

Thickness of cauda epididymis: It was measured as a distance between the anterior and posterior margins of the cauda.

Diameter of cauda epididymis: It was estimated as width+thickness/2, since the cross section of the tail was ovoid in shape.

The data was analyzed statistically by using SPSS software as per standard methods (Snedcor \& Cochran, 1967).

\section{RESULTS}

Observations on the testes and epididymis of Gaddi goats have been described in respective heads. The sample classification was based on the physiological status of the animals in prepubertal (birth to $<18$ months), pubertal ( $>18$ months to $<5 \mathrm{yr})$ and postpubertal ( $>5 \mathrm{yr}$ age) stages. A detailed description was thought desirable in neonatal animals for fixing a baseline for morphological development. A segmental temporal analysis of growth and development was also considered to be supplemented, hence in the description of prepubertal animals the status at birth (neonatal), 6 months, 12 months and 18 months have been inserted in the text along with overall description of growth and morphology and thence to compare the same in the pubertal and postpubertal animals as given in the summary data presented in the tables.

Testes. The two testes along with adnexa had reached their definitive location in the scrotum at the time of birth in the Gaddi goats. Both testes were elongated in shape with their long axis oriented vertically (Fig. 1). They were compressed latero-medially. But with the advancement of the age as the size of the testis increased, they became oval and convex laterally and relatively flat along the medial surfaces. The epididymis and vas deferens were attached along its posterior border. The anterior border was free and rounded. Dorsal and ventral extremities were covered with caput and cauda of the epididymis, respectively. Centrally placed mediastinum testis was present as a pulpy small cord in oneday-old kid. It increased in size and appeared as a whitish fibrous cord extending right from the dorsal extremity of the testis up to the distal 3/4th of its length in the later part of life of animal.

The right and left testes at birth measured 1.57 and $1.35 \mathrm{~cm}$ in length, $0.88,0.89,0.58$ and $0.93,0.95 \& 0.61 \mathrm{~cm}$ in width in their proximal, middle and distal thirds, respectively, and $0.83,0.85,0.60$ and $0.77,0.84 \& 0.63 \mathrm{~cm}$ in thickness at the three points, respectively. The estimated diameter (width+thickness/2) in the proximal, middle and distal third were measured $0.85,0.87$ and $0.59 \mathrm{~cm}$ and 0.85 , $0.89 \& 0.62 \mathrm{~cm}$ in the right and left testes, respectively. The right and left testes weighed 3.10 and $2.81 \mathrm{~g}$, respectively. Thus indicating a slightly longer and heavier right testis than the left one at birth in Gaddi kids. The size of both the testes increased very fast during the first six months of age. The right and left testes measured 6.22 and $5.95 \mathrm{~cm}$ in length, $3.73,3.84,2.97$ and $3.84,3.87$ and $2.47 \mathrm{~cm}$ in width in the proximal, middle and distal thirds, respectively. The thicknesses of the right and left testes were 4.13, 4.22, 2.45 and $4.72,4.33$ and $2.46 \mathrm{~cm}$, respectively at the three points 
between the two extremities. The diameter at the above points estimated 3.93, 4.03 and 2.62 ; and $4.31,4.33 \& 2.46 \mathrm{~cm}$ in the right and left testes, respectively. The respective weight of right and left testes at six months of age was $78 \mathrm{~g}$ and 86 $\mathrm{g}$, thus revealed metamorphosis during growth. The right testis although was longer (as in the new born kids) than the left, it weighed less than the left one. A close inception of the data revealed a faster growth in the diameter of the left testis than the right one particularly (in the width and thickness of testis) in the upper two thirds. The testicles there after showed very gradual and relatively slow growth rate. At twelve months, the weight of both the testes reached 100 g. The length of the right and left testes measured 5.62 and $5.65 \mathrm{~cm}$, respectively. The width, thickness and diameter (estimated) of right testis in the proximal, middle and distal segment was $4.46,4.56,3.46 \mathrm{~cm}$ and, $4.34,4.49,3.10 \mathrm{~cm}$ and $4.40,4.52,3.28 \mathrm{~cm}$, respectively. The same parameters of the left testis were $4.30,4.35,3.28 \mathrm{~cm} ; 4.36,4.59,3.42$ $\mathrm{cm}$ and $4.33,4.47$ and $3.35 \mathrm{~cm}$, respectively. At one year of age the two testes of goat were similar in weight, although, the left testis was insignificantly longer and thicker than the right one. This deficiency was compensated by the width of the right testis which was wider than the left at this age. After 12 months of age, the testis showed very mild increase in gross parameters.

In pre-pubertal animals (on the whole), the right testis was $5.39 \pm 0.45 \mathrm{~cm}$ long (range $1.57-6.52 \mathrm{~cm}$ ) on an average. The width, thickness and diameter at the proximal, middle and distal third of the testis were as shown in Table I. The average weight was $73.71 \pm 10.62 \mathrm{~g}$ (range 3.1-108 g). The left testis was $5.49 \pm 0.45 \mathrm{~cm}$ long, $3.69 \pm 0.35 \mathrm{~cm}$ wide (middle segment) and $3.85 \pm 0.37 \mathrm{~cm}$ (middle segment) in thickness. The diameter was $3.77 \pm 0.35 \mathrm{~cm}$ at the middle and the mean weight was $75.28 \pm 10.63 \mathrm{~g}$. The statistical analysis of the data revealed that the difference in the size and weight of right and left testes were not significant. Thus the overall mean weight (based on composite data) of the testes in prepubertal animals was $74.49 \pm 7.31 \mathrm{~g}$ (range 2.81-108 $\mathrm{g}$ ). The average length, width and thickness measured $5.45 \pm 0.33 \mathrm{~cm}$, $3.72 \pm 0.24 \mathrm{~cm}$ and $3.83 \pm 0.25 \mathrm{~cm}$ (in the middle), respectively. The diameter at the proximal, middle and distal segment was $3.49 \pm 0.23,3.77 \pm 0.24$ and $2.29 \pm 0.16 \mathrm{~cm}$, respectively (Table II).

In pubertal animals, the testis although grew in size and weight both with the progressive age, the change in either of the parameters were not as abrupt as observed in prepubertal animals. On an average the right and left testes of pubertal animals weighed $106.50 \pm 5.73$ (range 70-130 g) and $108.5 \pm 5.63 \mathrm{~g}$ (range $75-135 \mathrm{~g}$ ), respectively. The mean length, width (middle) and thickness (middle) of the right testis measured $6.66,4.54$, and $4.52 \mathrm{~cm}$, respectively. The same parameters in the left testis measured 6.69, 4.59 and $4.64 \mathrm{~cm}$, respectively. The diameter of the right testes measured $4.52 \mathrm{~cm}$ while that of the left testis measured 4.62 $\mathrm{cm}$ in the middle. The statistical analysis of the data revealed non-significant variation between the different parameters of the two testes. Therefore, the pooled mean weight of right and left testes was $107.50 \pm 3.92 \mathrm{~g}$ (Table I). The pooled mean of length, width and thickness were $6.68,4.57$ and $4.58 \mathrm{~cm}$, respectively. Similarly the overall mean diameter of the two testes was $4.57 \mathrm{~cm}$ in its middle.

In post-pubertal animals the testis grew only very slightly in size. The mean weight of right and left testes was $114.60 \pm 8.89(62-145 \mathrm{~g})$ and $112.80 \pm 9.61 \mathrm{~g}(57-145 \mathrm{~g})$, respectively. The mean length, width and thickness (in middle) of right testis measured $7.05,5.03$, and $5.29 \mathrm{~cm}$, respectively. The diameter at the middle was $5.16 \mathrm{~cm}$. The collateral figures for the left testis measured 7.07, 4.96, 5.22 and $5.08 \mathrm{~cm}$, respectively. The growth changes in these parameters were very slow over the previous age group. The overall mean length, width and thickness of the (right/left) testes were $7.06 \pm 0.33,4.99 \pm 0.19$, and $5.26 \pm 0.18 \mathrm{~cm}$, whereas the diameter was $5.12 \pm 0.18 \mathrm{~cm}$. The overall average weight of the (right/left) testes was $113.70 \pm 6.83 \mathrm{~g}$ (Table I).

Epididymis. Three parts viz; head (caput), body (corpus) and tail (cauda) were clearly identifiable in a day old kid (Fig. 1). The epididymis started from the dorsal extremity of the testis forming a globular flat rounded caput, which covered almost one fourth of the anterior border of the testis. It then turned on the lateral border and then descended along the postero-lateral border of the testis as the corpus. It ended as the cauda at the distal extremity of the respective testes. The tail was rounded or elongated tubercular like projection.

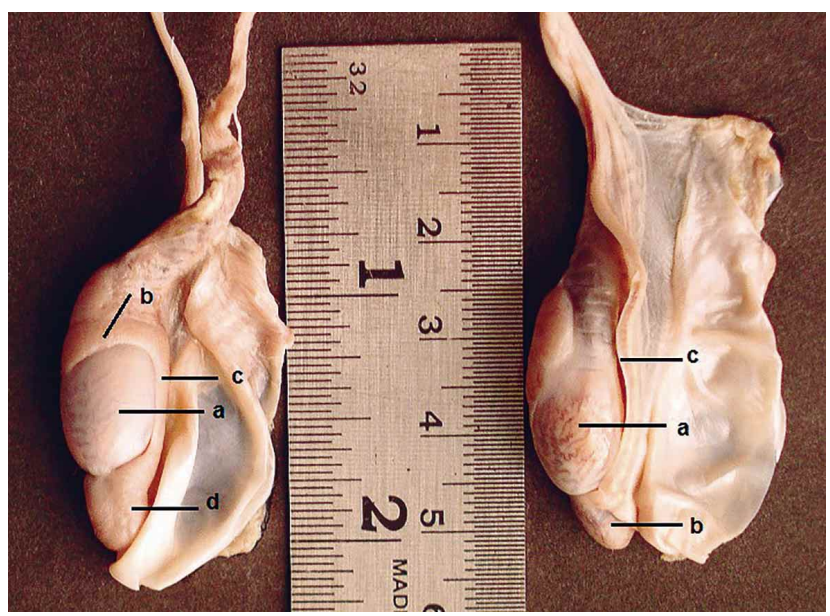

Fig. 1. Photograph of a day old Gaddi kid showing (A): lateral surface of testis (a), caput (b), corpus (c) an d cauda (d) of epididymis. (B): medial surface (a), cauda of epididymis (b) and vas deferens (c). 


\begin{tabular}{|c|c|c|c|c|c|}
\hline \multirow{2}{*}{$\begin{array}{l}\text { S. No. } \\
1\end{array}$} & \multicolumn{2}{|l|}{ Parameter } & \multirow{2}{*}{$\begin{array}{c}\text { Pre-Pubertal } \\
74.49^{\mathrm{a}} \pm 7.31\end{array}$} & \multirow{2}{*}{$\frac{\text { Pubertal }}{107.50 \mathrm{~b} \pm 3.92}$} & \multirow{2}{*}{$\frac{\text { Post-Pubertal }}{113.70^{\mathrm{b}} \pm 6.38}$} \\
\hline & Weight (g) & & & & \\
\hline & & & $(2.81-108)$ & $(70-135)$ & $(57-145)$ \\
\hline 2 & Length (cm) & & $\begin{array}{c}5.45 \mathrm{a} \pm 0.33 \\
(1.35-6.81)\end{array}$ & $\begin{array}{l}6.68^{\mathrm{b}} \pm 0.17 \\
(5.29-8.20)\end{array}$ & $\begin{array}{c}7.06 \mathrm{~b} \pm 0.33 \\
(5.20-10.03)\end{array}$ \\
\hline \multirow[t]{4}{*}{3} & \multirow[t]{4}{*}{ Width $(\mathrm{cm})$} & Proximal & $\begin{array}{c}3.46 \pm 0.23 \\
(0.88-4.46)\end{array}$ & $\begin{array}{c}4.20 \pm 0.12 \\
(3.10-5.23)\end{array}$ & $\begin{array}{c}4.73 \pm 0.22 \\
(3.20-6.74)\end{array}$ \\
\hline & & Middle & $3.72 \mathrm{a} \pm 0.24$ & $4.57^{b} \pm 0.85$ & $4.99 \mathrm{~b} \pm 0.19$ \\
\hline & & & $(0.89-4.58)$ & $(3.90-5.39)$ & $(3.88-6.82)$ \\
\hline & & Distal & $\begin{array}{c}2.33 \pm 0.17 \\
(0.58-3.46)\end{array}$ & $\begin{array}{c}2.56 \pm 0.87 \\
(1.90-3.20)\end{array}$ & $\begin{array}{c}2.75 \pm 0.11 \\
(1.74-3.94)\end{array}$ \\
\hline \multirow[t]{4}{*}{4} & \multirow[t]{4}{*}{ Thickness (cm) } & Proximal & $\begin{array}{c}3.49 \pm 0.25 \\
(0.77-4.72)\end{array}$ & $\begin{array}{c}4.24 \pm 0.11 \\
(3.19-5.06)\end{array}$ & $\begin{array}{c}4.86 \pm 0.19 \\
(3.43-6.90)\end{array}$ \\
\hline & & Middle & $3.83 \mathrm{a} \pm 0.25$ & $4.58^{\mathrm{ab} \pm 0.63}$ & $5.26 \mathrm{~b} \pm 0.18$ \\
\hline & & & $(0.83-4.79)$ & $(3.90-5.06)$ & $(3.81-7.04)$ \\
\hline & & Distal & $\begin{array}{c}2.24 \pm 0.16 \\
(0.60-3.42)\end{array}$ & $\begin{array}{c}2.42 \pm 0.10 \\
(1.90-3.60)\end{array}$ & $\begin{array}{c}2.92 \pm 0.14 \\
(2.20-4.65)\end{array}$ \\
\hline \multirow[t]{4}{*}{5} & \multirow[t]{4}{*}{ Diameter $(\mathrm{cm})$} & Proximal & $\begin{array}{c}3.49 \pm 0.23 \\
(0.85-4.40)\end{array}$ & $\begin{array}{c}4.22 \pm 0.11 \\
(3.35-5.14)\end{array}$ & $\begin{array}{c}4.79 \pm 0.20 \\
(3.49-6.81)\end{array}$ \\
\hline & & Middle & $3.77 \mathrm{a} \pm 0.24$ & $4.57^{b} \pm 0.07$ & $5.12 \mathrm{~b} \pm 0.18$ \\
\hline & & & $(0.87-4.63)$ & $(4.05-5.22)$ & $(3.90-6.93)$ \\
\hline & & Distal & $\begin{array}{c}2.29 \pm 0.16 \\
(0.59-3.35)\end{array}$ & $\begin{array}{c}2.49 \pm 0.09 \\
(1.95-3.40)\end{array}$ & $\begin{array}{c}2.83 \pm 0.12 \\
(2.10-4.26)\end{array}$ \\
\hline
\end{tabular}

$\mathrm{n}=10$. Figures in the parenthesis indicate the range; $\mathrm{a}, \mathrm{b}, \mathrm{c}, \ldots \ldots$ shows the significant difference between the groups.

Head (Caput epididymis). The caput epididymis was formed by the union of several ductuli efferentes. It was spread on the dorsal extremity of the testis in a "V" shaped manner. In one day old kids, the length, width and thickness of the right caput epididymis were $2.80,0.63$ and $0.41 \mathrm{~cm}$, respectively whereas the collateral figures for the left were $2.40,0.58$ and $0.51 \mathrm{~cm}$, respectively. These parameters increased rapidly with age as well as with the increase in the size of testis up-to six months of age. At about six months age, the length, width and thickness of the right caput epididymis were $9.50,2.54$ and $1.81 \mathrm{~cm}$, respectively. The same parameters in the left caput epididymis were 9.20, 2.54 and $1.95 \mathrm{~cm}$ respectively. After six months of age, the increase in these mensurations (of the caput epididymis) was very slow and gradual. The mean length, width and thickness of the right caput epididymis in pre-pubertal Gaddi goats were $8.09,2.22$ and $1.38 \mathrm{~cm}$, respectively. In the left caput epididymis these parameters were $9.20,2.54$ and $1.95 \mathrm{~cm}$, respectively. The statistical analysis of the data revealed no significant difference in the measurements of the right and left caput epididymis. Thus the overall mean length, width and thickness of the left and right prepubertal caput epididymis were $7.99 \pm 0.52$ (range $2.40-10.50 \mathrm{~cm}$ ), $2.21 \pm 0.51$ (range $0.58-2.84 \mathrm{~cm}$ ) and $1.37 \pm 0.11 \mathrm{~cm}$ (range $0.41-2.13 \mathrm{~cm}$ ), respectively (Table II).
In pubertal animals, the caput of the left epididymis was $9.4 \mathrm{~cm}(8.3-12 \mathrm{~cm})$ long, $2.74 \mathrm{~cm}(2.23-3.30 \mathrm{~cm})$ wide and $1.67 \mathrm{~cm}$ thick $(0.76-2.04 \mathrm{~cm})$. The same parameters of the right side were $9.71(8.8-10.4 \mathrm{~cm}), 2.73(2.29-3.4$ $\mathrm{cm})$ and $1.73 \mathrm{~cm}(0.78-2.15 \mathrm{~cm})$, respectively. The statistical analysis revealed no significant difference among these parameters of the right and left caput epididymis. Therefore, the overall average estimated values of left and right caput of the epididymis were $9.58 \pm 0.19 \mathrm{~cm}(8.30$ $12.00 \mathrm{~cm})$ in length, $2.74 \pm 0.07 \mathrm{~cm}(2.23-3.40 \mathrm{~cm})$ wide and $1.69 \pm 0.09 \mathrm{~cm}(0.76-2.15 \mathrm{~cm})$ in thickness (Table II).

In post-pubertal animals the mean length, width and thickness of the right caput epididymis were 10.02, 2.77 and $1.89 \mathrm{~cm}$, respectively. The same parameters of the left caput epididymis were $10.07,2.73$ and $1.80 \mathrm{~cm}$. The overall mean values of the left and right caput epididymis measured $10.05 \pm 0.46 \mathrm{~cm}(8.10-14.50 \mathrm{~cm})$ long, $2.75 \pm 0.10 \mathrm{~cm}(1.96-$ $3.90 \mathrm{~cm}$ ) wide and $1.85 \pm 0.07(1.24-2.50 \mathrm{~cm})$ thick (Table II).

Body (Corpus epididymis). In one day old kids the length, width and thickness of the corpus epididymis measured $2.30,0.35$ and $0.19 \mathrm{~cm}$ on the right; and $2.60 \mathrm{~cm}, 0.37 \mathrm{~cm}$ and $0.16 \mathrm{~cm}$ on the left side, respectively. At about 6 months 
Table II. Morphometrical parameters (Mean \pm S.E) of epididymis in Gaddi goats in various age groups.

\begin{tabular}{|c|c|c|c|c|c|}
\hline S.No. & Parameter & & Pre-Pubertal & Pubertal & Post-Pubertal \\
\hline \multirow[t]{3}{*}{1} & Caput $(\mathrm{cm})$ & Length & $\begin{array}{c}7.99^{a \pm}-0.52 \\
(2.40-10.50)\end{array}$ & $\begin{array}{c}9.58^{\mathrm{ab}} \pm 0.19 \\
(8.30-12.00)\end{array}$ & $\begin{array}{c}10.05^{\mathrm{b} \pm} 0.46 \\
(8.10-14.50)\end{array}$ \\
\hline & & Width & $\begin{array}{l}2.21^{\mathrm{a} \pm}-0.15 \\
(0.58-2.84)\end{array}$ & $\begin{array}{l}2.74 \mathrm{~b} \pm 0.07 \\
(2.23-3.40)\end{array}$ & $\begin{array}{c}2.75 \mathrm{~b} \pm 0.10 \\
(1.96-3.90)\end{array}$ \\
\hline & & Thickness & $\begin{array}{l}1.37^{\mathrm{a} \pm} 0.11 \\
(0.41-2.13)\end{array}$ & $\begin{array}{l}1.69^{\mathrm{ab}} \pm 0.09 \\
(0.76-2.15)\end{array}$ & $\begin{array}{c}1.85 \mathrm{~b} \pm 0.07 \\
(1.24-2.50)\end{array}$ \\
\hline \multirow[t]{3}{*}{2} & Corpus $(\mathrm{cm})$ & Length & $\begin{array}{l}5.82^{\mathrm{a} \pm}-0.31 \\
(2.30-8.00)\end{array}$ & $\begin{array}{c}7.51 \mathrm{~b} \pm 0.36 \\
(5.00-10.40)\end{array}$ & $\begin{array}{c}8.45 \mathrm{~b} \pm 0.48 \\
(5.32-12.50)\end{array}$ \\
\hline & & Width & $\begin{array}{c}0.71 \pm 0.04 \\
(0.35-1.03)\end{array}$ & $\begin{array}{c}0.83 \pm 0.60 \\
(0.45-1.62)\end{array}$ & $\begin{array}{c}0.89 \pm 0.06 \\
(0.52-1.81)\end{array}$ \\
\hline & & Thickness & $\begin{array}{c}0.29 \pm 0.05 \\
(0.13-0.90)\end{array}$ & $\begin{array}{c}0.29 \pm 0.02 \\
(0.20-0.54)\end{array}$ & $\begin{array}{c}0.24 \pm 0.01 \\
(0.14-0.37)\end{array}$ \\
\hline \multirow[t]{4}{*}{3} & Cauda $(\mathrm{cm})$ & Length & $\begin{array}{l}1.69^{\mathrm{a} \pm}-0.11 \\
(0.85-2.72)\end{array}$ & $\begin{array}{l}2.05^{\mathrm{ab}} \pm 0.06 \\
(1.60-2.44)\end{array}$ & $\begin{array}{c}2.33 \mathrm{~b} \pm 0.12 \\
(1.60-3.50)\end{array}$ \\
\hline & & Width & $\begin{array}{l}1.48^{\mathrm{a} \pm}-0.10 \\
(0.50-2.18)\end{array}$ & $\begin{array}{l}1.79^{\mathrm{ab}} \pm 0.06 \\
(1.50-2.84)\end{array}$ & $\begin{array}{c}1.83 \mathrm{~b} \pm 0.09 \\
(1.13-2.85)\end{array}$ \\
\hline & & Thickness & $\begin{array}{l}1.49^{\mathrm{a}}{ }^{ \pm} 0.09 \\
(0.47-2.18)\end{array}$ & $\begin{array}{c}1.88 \mathrm{~b} \pm 0.05 \\
(1.50-2.36)\end{array}$ & $\begin{array}{l}1.88 \mathrm{~b} \pm 0.09 \\
(1.08-2.85)\end{array}$ \\
\hline & & Diameter & $\begin{array}{l}1.48^{\mathrm{a} \pm} 0.09 \\
(0.48-1.98)\end{array}$ & $\begin{array}{l}1.83 \mathrm{~b} \pm 0.04 \\
2.33 \mathrm{~b} \pm 0.12\end{array}$ & $\begin{array}{c}1.86 \mathrm{~b} \pm 0.09 \\
(1.10-2.74)\end{array}$ \\
\hline
\end{tabular}

$\mathrm{n}=10$. Figures in the parenthesis indicate the range. $\mathrm{a}, \mathrm{b}, \mathrm{c}, \ldots \ldots$ shows the significant difference between the groups.

of age these measurements in the right corpus epididymis were $5.90,0.72$ and $0.20 \mathrm{~cm}$, whereas, in left corpus epididymis it were $5.30,0.77$ and $0.17 \mathrm{~cm}$, respectively. At 1 year of age the same parameters in right and left corpus epididymis were $6.60,0.99,0.29 \mathrm{~cm}$ and $6.60,0.88$ and $0.28 \mathrm{~cm}$, respectively. The data indicated only a very mild increase in the parameters of corpus epididymis from 6 months to 12 months of age. The statistical analysis of the data revealed a significant difference between the length of right and left corpus epididymis indicating larger left corpus epididymis than the right one. The overall mean length of the right and left corpus epididymis in prepubertal Gaddi goats was $5.64 \pm 0.43$ and $6.00 \pm 0.48 \mathrm{~cm}$, respectively (Table II).

The length, width and thickness of the corpus epididymis of the pubertal Gaddi goats measured 7.94 (5.3$10.4 \mathrm{~cm}), 0.88(0.5-1.62 \mathrm{~cm})$ and $0.31 \mathrm{~cm}(0.2-0.54 \mathrm{~cm})$ on the left; and $7.08(5.00-9.50 \mathrm{~cm}), 0.78(0.45-1.10 \mathrm{~cm})$ and $0.26 \mathrm{~cm}(0.2-0.45 \mathrm{~cm})$ on the right side, respectively. The statistical analysis of the data revealed a significant difference among the length of right and left corpus epididymis. But there was no significant difference between the width and the thickness of the right and left corpus epididymis. Thus the overall mean width and thickness of the right and left corpus epididymis was estimated to be $0.83 \pm 0.60(0.45-1.62 \mathrm{~cm})$ and $0.29 \pm 0.02$ $\mathrm{cm}(0.20-0.54 \mathrm{~cm})$ respectively (Table II).

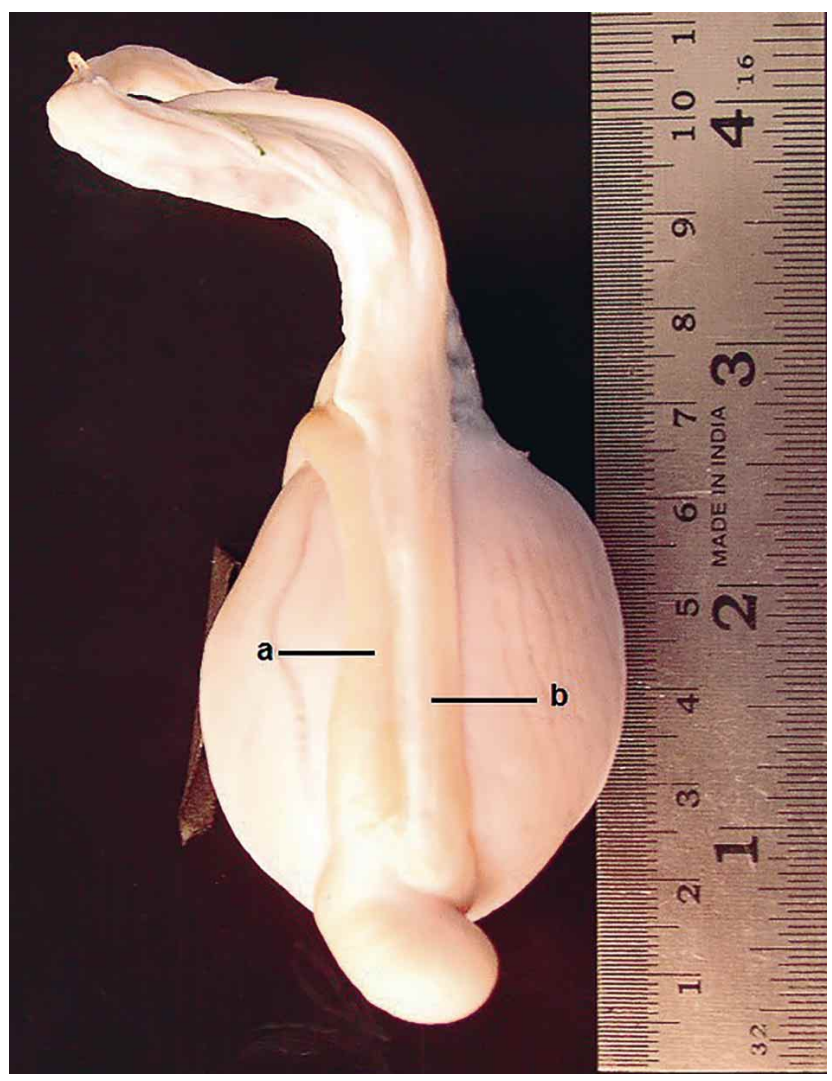

Fig. 2. Photograph of Internal genital organs of pubertal Gaddi goat showing ampullae (a), vesiculae seminalis (b), pelvic urethra (c) and bubourethral glands (d). 
In post-pubertal goats, the length, width and thickness of the left corpus epididymis measured 8.52, 0.83 and $0.24 \mathrm{~cm}$, respectively. The right corpus epididymis measured $8.39,0.96$ and $0.24 \mathrm{~cm}$ in length, width and thickness, respectively. The overall mean width and thickness of the right and left corpus epididymis was estimated $0.89 \pm 0.68$ (range $0.52-1.81 \mathrm{~cm}$ ) and $0.24 \pm 0.01$ $\mathrm{cm}$ (range $0.410-0.37 \mathrm{~cm}$ ), respectively (Table II).

Tail (Cauda epididymis). The cauda of epididymis was rounded to elongated in shape. Its length, width, thickness and diameter measured $0.85,0.50,0.47$ and $0.48 \mathrm{~cm}$ in the right and $0.86,0.51,0.59$ and $0.55 \mathrm{~cm}$, respectively in the left epididymis of the one day old kids. These parameters increased with age. The mean length, width, thickness and diameter of the right cauda epididymis measured $1.85,1.95,1.95$ and $1.95 \mathrm{~cm}$, respectively and $1.65,1.68,1.75$ and $1.71 \mathrm{~cm}$ in the left cauda epididymis of 6 months old kids. At 12 months, the length, width, thickness and diameter of the left cauda epididymis was $2.11,1.58,2.18$ and $1.88 \mathrm{~cm}$, respectively. The same parameters in the right measured 2.72, 1.62, 2.03 and 1.82 $\mathrm{cm}$. The overall length, width, thickness and diameter of cauda epididymis in pre-pubertal Gaddi goats were 1.61, $1.52,1.51$ and $1.48 \mathrm{~cm}$ on the left side and $1.79,1.50 \mathrm{~cm}$, $1.49 \mathrm{~cm}$ and $1.49 \mathrm{~cm}$ on the right side, respectively. The statistical analysis revealed no significant difference between the parameters of the right and left cauda epididymis. Thus the overall mean length, width, thickness and diameter of the right and left cauda epididymis in pre-pubertal animals were $1.69 \pm 0.11$, $1.48 \pm 0.10$, and $1.49 \pm 0.09$ and $1.48 \pm 0.09 \mathrm{~cm}$, respectively (Table II).

In pubertal animals, the mean length, width, thickness and diameter of the left cauda epididymis measured $2.04,1.74,1.89$ and $1.81 \mathrm{~cm}$ respectively, whereas, the values for similar parameters were $2.08,1.83$, 1.87 and $1.84 \mathrm{~cm}$, respectively on the right side. The overall mean parameters (length, width, thickness and diameter) of the combined left and right cauda epididymis of pubertal Gaddi goats measured 2.05 $\pm 0.06,1.79 \pm 0.06$, and $1.88 \pm 0.05$ and $1.83 \pm 0.04 \mathrm{~cm}$, respectively (Table II).

In post-pubertal animals, the length, width, thickness and diameter of the left cauda epididymis measured $2.37,1.82,1.89$ and $1.85 \mathrm{~cm}$, respectively. The same parameters on the right side measured 2.29, 1.85, 1.87 and $1.85 \mathrm{~cm}$, respectively. The overall mean parameter of the right and left cauda epididymis measured $2.33 \pm 0.12$ (range 1.60-3.50 cm), 1.83 \pm 0.09 (range 1.13$2.85 \mathrm{~cm}$ ), $1.88 \pm 0.09$ (range $1.08-2.85 \mathrm{~cm}$ ) and $1.86 \pm 0.09$ $\mathrm{cm}$ (range 1.10-2.74 cm), respectively (Table II).

\section{DISCUSSION}

In the Gaddi goats, the two testes had descended completely in the scrotum and lay vertically placed along with the adnexa in it at the time of birth and through the whole life as in other farm animals (Geity, 1975). In the kids of Gaddi goats, at birth, the testes were elongated and compressed latero-medially but became more convex and ovoid at puberty and beyond. The final shape of the goat testes compared more closely with that of the buffalo bull (Chandra Pal, 1976) than the ram, which was stated to be more broader in proportion than the length (Geity).

The mediastinum testis appeared as a grey cord like structure at birth but became more condensed and rich in fibrous white tissue, reaching from the proximal extremity to the distal 3/4th of its length at puberty and beyond, in Gaddi bucks. Lobuli testis became prominent only in adult post-pubertal testis. Similar views were also reported in bovines (Geity; Chandra Pal). In newborn Gaddi kids a longer and heavier right testis was observed when compared to the left one but at six months the left testis became heavier than the right; although the length of the latter remained more. This indicated metamorphosis in the shape of the testes during the growth process in the first six months of postnatal age. Present findings are in agreement with reports of Nwoha, who could not find a direct correlation between the length, diameter and area of testes with its weight and hence, had no relevance with the reproductive performance assessment of the Japanese goats.

The weight of both the testes grew faster in the first six months of postnatal life, when it grew almost thirty times heavier than its weight at birth. The weight and size of left and right testes did not differ significantly in the late pre-pubertal goats. Similar observations have been made in Assam goats (Baishya et al., 1985); where the measurements of either testis did not differ significantly between $0-90$ days. The mean weight of testes was about $3 \mathrm{~g}, 75 \mathrm{~g}, 108 \mathrm{~g}$ and $114 \mathrm{~g}$ in neonates, prepubertal, pubertal and post-pubertal Gaddi goats, respectively, which indicated a very fast growth $(>30 \mathrm{X})$ of testis in pre-pubertal animals beyond which it grew $50 \%$ more in pubertal and only $5 \%$ more in the postpubertal animals. Ogwuebu et al., have correlated the weight of testis with sperm reserve. The present results almost confirmed the growth trend of testes of Ossimi lambs as reported by Khalil et al. (1995) where it grew for $>5 \mathrm{X}$ between $6-10$ months but only $<2 \mathrm{X}$ between 10-14 months. Gupta also recorded similar observations on the Beetal goats' testis and stated that the gain in the 
testicular weight was of a lower magnitude during (1824 months) than in 0-12 months. Deshpande \& Mehta (1992) observed 2.5-3 times growth of the scrotal circumference of Marwari and Surti kids at 12 months of age, which also directly indicated the size of testes as also reported by Barnabe et al.; Nishimura et al., recorded $4 \mathrm{X}$ increment in the testicular weight during 3-12 months age in Tokara (Japanese) goats. Salhab et al. (2001) also reported fastest testicular weight gain between 7-10 months in Awassi rams.

The epididymis of Gaddi goats arose from the proximal extremity of testis as a globular flat "V" shaped structure covering its dorsal and anterior 1/4th surface. It then ran along the caudo lateral border of testis to reach at its distal extremity to end as the cauda in the form of a tubercular mass. Thus the epididymis was identified into three parts- caput, corpus and cauda as also in other domestic animals (Geity). At birth the head and the tail of the right epididymis measured slightly more (although statistically insignificant) than the left one, whereas, the length was more of the left epididymis (statistically significant) in the prepubertal animals. But this ratio was reversed in the post-pubertal animals in respect of the caput and cauda which became longer on the left side. The corpus, however, remained always longer in the left epididymis throughout the life of the animal. The overall growth and metamorphosis was faster in the epididymis of the younger kids ( $<6$ months) than in the older ones (>6months). Although all the components of the epididymis grew with age; the morphometrical changes were more drastic in caput and cauda region and more so in the latter. A gradual and consistent transition occurred in the length and thickness of all the three components of the epididymis, but the differential growth was more appreciable during the prepubertal to pubertal stages of life than in the later phases of life of animal. Similar observations were recorded by Yao \& Eaton (1954), Watson et al. (1956), Terril (1968) and Harshan et al. in goats of various breeds.

Gupta reported a higher (composite) right epididymal weight than the left one and stated that the weight and the size of the epididymis grew in a linear manner with the advancement of age in Beetal goats. Goyal \& Dhingra (1973) although found no appreciable difference between the right and left epididymis, stated that the epididymal length increased with age in buffalo.

PATHAK, A.; KATIYAR, R. S.; SHARMA, D. N. \& FAROOQUI, M. M. Desarrollo anatómico postnatal de los testículos y epidídimo de cabras Gaddi. Int. J. Morphol., 32(4):1391-1398, 2014.

RESUMEN: El estudio reveló que los testículos de las cabras Gaddi, de un día de edad, descienden al escroto junto con sus anexos. Se elongaron en dirección latero-medial y convirtieron en ovoides durante su crecimiento postnatal y en la morfogénesis. Los dos testículos no fueron significativamente diferentes en su peso y medidas. El peso promedio fue aproximadamente de $2,9 \mathrm{~g}$ al nacer, $\mathrm{y}$ aumentó a $107 \mathrm{~g}(40 \mathrm{X})$ en animales púberes y casi mantuvo su peso durante la post-pubertad (113 g). La longitud (1,46 cm), ancho (0,85 $\mathrm{cm})$ y espesor $(0,62 \mathrm{~cm})$ también crecieron unas 47,60 y 83 veces, respectivamente. En los animales post-puberales las medidas fueron de 7,06 x 5,20 x $5.10 \mathrm{~cm}$. Se observó un crecimiento muy rápido de los testículos desde el nacimiento hasta la pubertad, sin alterarse de manera significativa posteriormente. Un crecimiento relativamente mucho más rápido en espesor y anchura, sobre la longitud, fue la razón detrás del cambio de la morfología desde la forma más alargada, presente en el nacimiento, a la forma ovoide de la madurez. El mediastino testicular fue claramente identificado en el testículo, inclusive en el nacimiento. En el epidídimo se identificaron las porciones de la cabeza, cuerpo y cola. La medición lineal de estos componentes no difirió en las regiones de la cabeza y cola de cada lado, mientras que la longitud del cuerpo fue mayor en el lado izquierdo en todos los grupos. La curva de crecimiento reveló un crecimiento continuo de todos los segmentos, pero el mayor crecimiento se produjo en la vida postnatal temprana (entre los 12 y 18 meses).

PALABRAS CLAVE: Desarrollo postnatal; Anatomía; Testículos; Epidídimo; Cabras Gaddi.

\section{REFERENCES}

Baishya, G.; Ahmed, S. \& Bhattacharya, M. Gross anatomical observations on male gonad and thyroid gland in Assam goat (Capra hircus) during postnatal life (zero to ninety days). Indian Vet. J., 62:395-400, 1985.

Baishya, G.; Ahmed, S. \& Bhattacharya, M. A correlative study on biometry and histomorphometry of male gonad and thyroid gland (0-90 days) in Assam goat (Capra hircus). Indian Vet. J., 63(11):928-32, 1986.
Barnabe, R. C.; Villar Filho, A. C.; Birgel, E. H. \& Barnabe, V. H. Testis and semen study of bucks raised in the semi-arid region of Paraiba State (North-East Brazil). São Paulo, University of Sao Paulo, V International Conference Goats, 1992.

Chandra Pal. Gross, histological and histochemical studies on the male genital system of buffalo (Bubalus bubalis). Ph.D. Thesis. Agra, Agra University, 1976. 
Deshpande, B. \& Mehta, V. M. Age related biochemical profiles of buck testis. São Paulo, University of São Paulo, V International Conference Goats, 1992.

Geity, R. (Ed.). Sisson \& Grossman's The Anatomy of the domestic animals. $5^{\text {th }}$ ed. Philadelphia, W. B. Saunders Co., 1975. pp.7689.

Goyal, H. O. \& Dhingra, L. D. A study on the postnatal histology of the testis in buffalo (Bubalus bubalis). I. From birth to one year. Acta Anat. (Basel), 84(2):237-50, 1973.

Gupta, A. N. Correlative Anatomy of the testes, epididymis \& accessory sex glands in goat. Ph.D. Thesis. HAU Hisar, 1989.

Harshan, K. R; Radhakrishnan K.; Omer, P. A. \& Paily, L. Postnatal development of epididymis in Malbari goats (Capra hircus). Kerala J. Vet. Sci., 9(2):279-89, 1978.

Khalil, I. A.; El-Sayed, A. I.; Abdel-El-Ghafar, A. E. \& Mousa, M. E. Plasma testosterone level and histology testes and epididymis of Ossimi male lambs in relation to age. Ann. Agric. Sci. Moshtohor, 33(4):1237-50, 1995.

Nishimura, S.; Okano, K.; Yasukouchi, K.; Gotoh. T.; Tabata, S. \& Jwamoto, H. Testis developments and puberty in the male Tokara (Japanese native) goat. Anim. Reprod. Sci., 64(12):127-31, 2000.

Nwoha, P. U. Seasonal variation in the correlation of testicular and epididymal weight-dimensions in the red Sokoto goat and white Yankassa ram. Kaibogaku Zasshi, 71(1):9-14, 1996.

Ogwuegbu, S. O.; Oke, B. O. \& Akusu, M. O. Gonadal and extra gonadal sperm reserves of Maradi (Red Sokoto) goat. Bull. Anim. Health Prod. Afr., 33:139-41, 1985.

Pathak, A.; Katiyar, R. S.; Sharma, D. N.; Farooqui, M. M. \& Prakash, A. Gross anatomical, histological and histochemical studies on the postnatal development of the prostate gland of Gaddi goat. Int. J. Morphol., 30(2):731-9, 2012.

Salhab, S. A.; Zarkawi, M.; Wardeh, M. F.; Al-Masri, M. R. \& Kassem, R. Development of testicular dimensions and size, and their relationship to age, body weight and parental size in growing Awassi ram lambs. Small Rumin. Res., 40(2):187-91, 2001.

Snedecor, G. W. \& Cochran, W. G. Statistical methods. $6^{\text {th }}$ ed. Calcutta, Oxford and IBH Publishing Co., 1967.

Terril, C. E. Sheep. In: Hafez, E. S. E. (Ed.). Reproduction in farm animals. 2nd ed. Philadelphia, Lea and Febiger, 1968. p.265.

Walkden-Brown, S. W.; Restall, B. J. \& Taylor, W. A. Testicular and epididymal sperm content in grazing Cashmere bucks: seasonal variation and prediction from measurements in vivo. Reprod. Fertil. Dev., 6(6):727-36, 1994.
Watson, R. H.; Sapsford, C. S. \& McCance, I. The development of the testis, epididymis, and penis in the young Merino ram. Aust. J. Agric. Res., 7(6):574-90, 1956.

Yao, T. S. \& Eaton, O. N. Postnatal growth and histological development of reproductive organs in male goats. Am. J. Anat., 95(3):401-31, 1954.

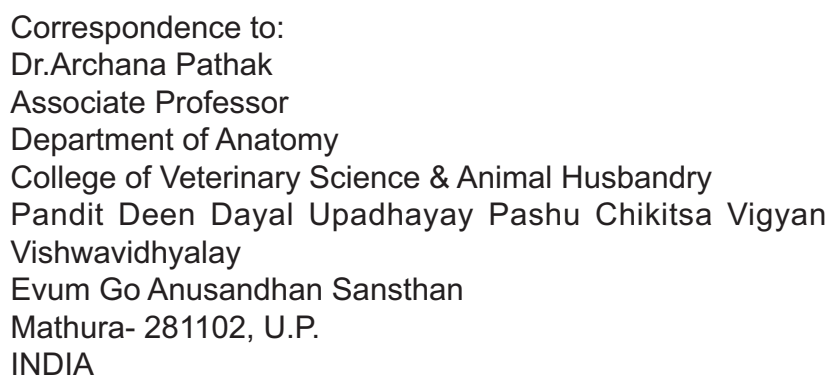

Phone: +91-9458030888

Email: pathak_arcvik@yahoo.com

Received: 06-06-2014

Accepted: 27-09-2014 